\title{
Menemukan Misi dalam Teologia Pendidikan Melalui Pemilihan dan Tanggung Jawab Israel
}

\section{Finding Mission in Educational Theology Through Election and Israel Responsibility}

Noh I. Boiliu, ${ }^{1}$ Fransiskus I. Widjaja, ${ }^{2}$ Evi Deliviana, ${ }^{4}$ Aeron F. Sihombing, ${ }^{4}$ Yanice A. Janis, ${ }^{5}$

\author{
${ }^{1}$ Prodi Pendididkan Agama Kristen, Fakultas Keguruan dan \\ Ilmu Pendidikan, Universitas Kristen Indonesia, Jakarta \\ ${ }^{2}$ Program Pascasarjana STT Real Batam, Kepulauan Riau \\ ${ }^{3}$ Prodi Bimbingan dan Konseling, Fakultas Keguruan \\ dan Ilmu Pendidikan, Universitas Kristen Indonesia, Jakarta \\ ${ }^{4}$ STT SAPPI Ciranjang, Cianjur \\ ${ }^{5}$ Prodi Pendidikan Agama Kristen \\ Institut Agama Kristen Negeri Manado, Manado \\ boiliunoh@gmail.com
}

\begin{abstract}
Israel's election as God's people (am Yahweh) is the basis for God's relationship with Israel. "Election" becomes an important point in the Old Testament theological structure, which is the testimony of the Old Testament faith. YHWH'S election of Israel was the subject of Israel's call to improve and be in YHWH's relationship-Israel and Israel are responsible for witnessing YHWH's faith. Israel must also strengthen the Law as a manifestation of YHWH's will in the midst of Israel, as well as in the witness of the faith of Yahwis to other nations. Israel as a Yahwist faith community is responsible for responding to YHWH in responses in words and responses in action. Inward and outgoing missions are important points in the framework of Israel's election and Israeli responsibility. To achieve this mission (in and out) within the framework of Israel's selection and responsibility, teaching centered on the Torah must be carried out, with a locus, Israel as a community with family as first place
\end{abstract}

Keywords: Election, Responsibility, Mission, Christian Familly 


\section{Abstrak}

Pemilihan Israel sebagai umat Allah (am Yahweh) menjadi dasar bagi hubungan Allah dengan Israel. "Pemilihan" menjadi poin penting dalam struktur teologi, yakni kesaksian iman Perjanjian Lama. Pemilihan YHWH atas Israel menjadi pokok panggilan kepada Israel untuk mengingkatkan diri dan berada dalam hubungan YHWH-Israel dan Israel bertanggungjawab menyaksikan iman yang berpusat pada YHWH. Israel juga harus mengokohkan Taurat sebagai perwujudan kehendak YHWH di tengah Israel, maupun dalam kesaksian iman Yahwis kepada bangsa lain. Israel sebagai komunitas iman Yahwis bertanggungjawab merespons YHWH dalam respons di dalam kata (respons in words) dan respons di dalam tindakan (respons in action). Misi ke dalam dan misi keluar menjadi pokok penting dalam kerangka pemilihan Israel dan tanggung jawab Israel. Untuk mencapai misi tersebut (ke dalam dan keluar) dalam kerangka pemilihan dan tanggung jawab Israel, pengajaran yang berpusat pada Taurat harus dilakukan, dengan lokus, Israel sebagai komunitas dengan keluarga sebagai tempat pertama.

Kata kunci: Pemilihan, Tanggung Jawab, Misi, Keluarga Kristen

\section{PENDAHULUAN}

Pada abad ini, gereja menghadapi tantang dalam (ber) misi. Perubahan sosial masyarakat menjadi tantangan nyata dan gereja harus berupaya menciptakan dan memaksimalkan pendekatan-pendekatannya dalam merealisasikan Amanat Agung Tuhan Yesus (Great commandment). Dalam artikel yang ditulis oleh Ai Tizon, ${ }^{1}$ dan dalam analisisnya terhadap Magnum Opus David Bosch, bahwa kita berada dalam tantangan zaman dan karena itu kita harus membuat formulasi baru. Bernhard Ott, ${ }^{2}$ mengusulkan agar kita berupaya menemukan tempat untuk misi dalam teologia pendidikan. Pendekatan Ott juga menginspirasi Tizon dalam upaya menemukan pendekatan bagi misi. Wesley Woo, ${ }^{3}$ berusaha menolak misi yang bersifat individual sekaligus sebagai lokus.

Artikel ini berbeda dari artikel-artikel di atas, sebab artikel ini mencoba untuk mengulas kembali pemilihan dan tanggung jawab Israel dalam perspektif teologia Perjanjian Lama sebagai "pintu masuk" untuk meletakan dasar bagi tugas misi. Kerangka kerja praktis metodologis (metodologis karena selain menjelaskan, juga mencari pendekatan) menempatkan keluarga Kristen masa kini sebagai lokus dan Pendidikan Agama Kristen sebagai pendekatan.

\footnotetext{
${ }^{1}$ Al Tizon, "Mission as Education : A Past-to- Future Look at INFEMIT / OCMS" 4, no. 28 (2011): 253-264.

2 Bernhard Ott, "Mission and Theological Education" 18, no. 2 (2016): 87-98.

3 Wesley Woo, "Mission Development: Practical Confession Seminar Presentations on Themes" 61, no. 1 (2015): 162-66.
} 


\section{METODE}

Pendekatan yang digunakan dalam penulisan artikel ini adalah bersifat deskriptif (deduktifis) dengan mengumpulkan sumber-sumber pustaka berkaitan dengan "pemilihan, tanggung jawab" dalam perspektif Perjanjian Lama. Sumbersumber terkait tema dibahas dan dianalisis untuk melihat keluarga sebagai lokus pengajaran.

\section{TEORI}

\section{Pengertian Pemilihan}

Preuss ${ }^{4}$ memahami tindakan pemilihan dan kewajiban YHWH (secara historis) mengenai Israel telah diusulkan sebagai pusat yang mungkin merupakan ungkapan khas dan menjadi struktur fundamental terpenting dari kesaksian iman Perjanjian Lama. Istilah pemilihan secara spesifik merujuk pada akar kata "bāhar ("untuk memilih atau menentukan)" kita "yang menyaksikan aktivitas pemilihan YHWH untuk memberikan gambaran umum tentang kata-kata yang muncul dalam lingkup linguistik tentang konsep ini."6 Di sisi lain, secara khusus menunjuk pada kesadaran bahwa "aktivitas pemilihan YHWH terdiri dari struktur dasar kesaksian Perjanjian Lama yang paling menentukan."7 Konsepsi dan iman pemilihan adalah dasar kedua bagi kesadaran diri Israel dan cara hidupnya. "Vriezen memahami kata bahar memiliki ekspresi konsep yang kuat seperti kata pemilihan. Walaupun ada kata yang lain seperti yada, qara yang juga memiliki aspek seperti bahar (pemilihan) tetapi merupakan lapisan kedua dari ide pemilihan."

Istilah "pemilihan" yang dibahas dalam artikel ini berhubungan dengan pemilihan Israel. Pemilihan tidak dapat "ditepikan" sebagai salah satu tema teologis dalam Perjanjian Lama. Menempatkan pemilihan ${ }^{9}$ dalam proses menuju pengesahan merupakan pilihan terbaik. Sebagai tema penting dalam Perjanjian Lama, maka ide pemilihan harus ditempatkan dalam tema perjanjian (covenant). Pemilihan dan perjanjian adalah dua hal yang berbeda. Edmond Jacob ${ }^{10}$ menempatkan tema pemilihan sebagai salah satu tema sentral dalam Perjanjian Lama meski mungkin dianggap tidak sepenting perjanjian. Namun bagaimana pun, melalui pemilihan, Allah datang dan bersama Israel berada dalam hubungan.

\footnotetext{
${ }^{4}$ H. D. Preuss, Old Testament Theology (Kentucky: Westminter, 2007), 118.

$5 \mathrm{~J}$. McKeown, Dictionary of the Old Testament: Pentateuch, ed. T. Desmond Alexander and David W. Baker (Downers Grove, IL: Intervarsity Press, 2003), 116.

${ }^{6}$ Preuss, Old Testament Theology, 27.

7 lbid.

${ }^{8}$ Seock Tae Sohn, The Divine Election of Israel (Oregon: Wipf and Stock Publishers, 1991), 2.

9 lbid., 3.

${ }^{10} \mathrm{~S}$. Temjen Imchen, "The Election of Israel : A Theological Critique," Indian Journal of Theology 1, no. 2 (2001): 23-29.
} 
Bahkan, setiap "intervensi"" oleh Allah dalam sejarahnya adalah sebagai pemilihan.

Pada masa para patriakh, ada bagian dalam Perjanjian Lama yang mencatat tentang pemilihan Abraham dan kemudian Musa. Bagian ini merupakan "represent the divine choice of Israel as made in the time of Patriach and especially of Abraham, and Moses." 12 Allah memilih Abraham dan Musa dan kemudian membuat perjanjian. Allah mendeklarasikan eksisten Israel, dimulai dari para patriakh.

Menghubungkan pemilihan dengan kisah keluaran merupakan cara pendekatan untuk memahami pemilihan. Sebab "kisah keluaran merupakan pilihan utama."13 Kisah keluaran di bawah kepemimpinan Musa merupakan "tradisi sumber Priest (P) dalam cerita Musa." 14 Apa yang "dilaporkan dalam P lebih merupakan peristiwa antara YHWH dan "Mesir" di mana YHWH menang (Kel 14: 4, 8, 17)." ${ }^{15}$ Bahkan bagi Preuss, ${ }^{16}$ tindakan YHWH, selain itu, memiliki efek pedagogis untuk Israel (Kel 14: 15). dan, seperti telah terlihat dalam P, misalnya "Kejadian $1: 1-2: 3 ; 5: 1-28) ",{ }^{17}$ narasi tersebut membuktikan kekuatan firman ilahi (Kel. 14:26).

Tradisi $\mathrm{P}$ sepakat dengan apa yang benar-benar penting, dan itu tidak lain adalah teks tertua, Kel. 5:21, YHWH adalah Allah yang bertindak dengan kekuatan dalam sejarah, Ia adalah yang mampu membebaskan dan menuntun dengan caranya sendiri. Redaktur yang mengumpulkan narasi dari penulis yang berbeda juga mengenali dan memberi kesaksian akan fakta ini. Dalam proses redaksional, deskripsi oleh $\mathrm{P}$ diberi dominasi tertentu, walaupun sering dimodifikasi oleh penggabungan $\mathrm{J}^{18}$

Modifikasi atau penggabungan "sejarah J menyediakan sebuah transisi dari masa periode para patriakh berada dalam penindasan Mesir dan nantinya pembebasan dilakukan oleh Musa...P melengkapi J dalam Keluaran 1:7."19 Tradisi $P$ tidak hanya mencatat tentang kisah keluaran tetapi "juga mencatat tentang para

\footnotetext{
11 John Muddiman and John Barton, eds., The Pentateuch: Oxford Bible Commentary (Oxford: Oxford University Press, 2010), 105. Dalam kisah Israel keluar dari Mesir. Tindakan akhir Allah untuk menghukum Mesir sebagai benang merah dari pemilihan atas Israel.

12 Imchen, "The Election of Israel : A Theological Critique."

13 Preuss, Old Testament Theology.

14 David M. Carr, Introduction to the Old Testament: Sacret Text and Imperial Context of the Hebrew Bible (Oxford: Wiley Blackwell, 2010), 196.

15 Preuss, Old Testament Theology.

16 lbid.

${ }^{17}$ Carr, Introduction to the Old Testament: Sacret Text and Imperial Context of the Hebrew Bible, 196.

18 Preuss, Old Testament Theology.

19 John van Seters, The Pentateuch: A Social-Science Commentary (England: Sheffield Academic Press, 1999), 160.
} 
patriakh Israel." ${ }^{20}$ Catatan ini sekaligus memberikan arahan bahwa pemilihan berawal dari "pemilihan individu", ${ }^{21}$ seperti juga dikemukakan Preuss.

\section{Pemilihan dan Tanggung jawab Israel}

Preuss $^{22}$ memberikan catatan mengenai Israel, bahwa Israel mengenal Allah YHWH sebagai "YHWH dari tanah Mesir" (Hos. 12: 10; 13: 4). Sebagai ungkapan penting dari Dekalog menunjukkan hal tersebut (Kel. 20: 2; Ul. 5: 6), pengakuan tentang YHWH mengacu pada keluaran dari Mesir dan pembebasan di laut. Tindakan ini sebagai tindakan ilahi yang menentukan dan yang mengarah pada pembentukan sebuah komunitas antara YHWH dan Israel baik di luar maupun di dalam landasannya. Dalam tindakan yang menentukan ini, kesaksian Perjanjian Lama kepada Tuhan menemukan asal-usul dan pusatnya. Ini berarti bahwa definisi utama dari nama ilahi dalam ungkapan, "Akulah YHWH, Allahmu," ditangkap dalam pernyataan berikut: siapa yang telah membawa engkau keluar dari tanah Mesir, keluar dari rumah perbudakan." Penjelasan tentang nama ilahi ini tidak "ditambahkan sebagai definisi sekunder," untuk hubungan antara YHWH dan Israel tidak berasal baik dalam mitos prasejarah atau dalam ikatan alam. Sebaliknya, Yahweh masuk ke dalam sejarah untuk bertindak atas nama bagi bangsanya menjadi pengakuan yang kekal. Pembebasan ini pada saat bersamaan, merupakan pemilihan, memang, dalam pembebasan ini, Israel melihat "keutamaan pemilihan."

Pemilihan Israel dan akan disahkan melalui perjanjian, Israel dipilih oleh Allah menjadi "umat Allah atau am YHWH." ${ }^{23}$ Penambahan YHWH pada am menunjukkan hubungan khusus YHWH-Israel. Misalnya ditemukan:

'am yhwh ("YHWH's people") in the Pentateuch's oldest strata (e.g., Judg. 5:11, 13-an ancient Hebrew poem; and Num. 11:29; 16:41). Here it refers to either the members of Israel's tribal confederation (Judges) or the Israelite community on the march through the wilderness following its flight from Egypt (Numbers). It is present much more frequently in Dtr, where it denotes those faithful bound by the Deuteronomic covenant (Deut. 27:9-le ‘am layhwh); Israel before the establishment of the monarchy (1 Sam. 2:24) ${ }^{24}$

\footnotetext{
20 Joel S. Baden, The Composition of the Pentateuch: Renewing the Documentary Hypothesis (New Haven \& London: Yale University Press, 2012), 169-172.

21 Preuss, Old Testament Theology, 28. Para nabi tidak menggunakan bāhar untuk memberikan definisi perkiraan untuk arti panggilan mereka. Ini mungkin karena mereka berdiri dalam perlawanan kritis terhadap orang-orang percaya yang merupakan "orang-orang pilihan."

22 Ibid., 40.

${ }^{23} \mathrm{lbid} ., 51$. am YHWH berbeda dengan goy. Sebutan goy termasuk Israel dan orang di luar Israe. Sedangkan iam YHWH hanya untuk Israel.

${ }^{24}$ Gale A. Yee, Hugh R. Page Jr, and Matthew J.M Coomber, eds., The Pentateuch: Fortress Commentary on the Bible Study Edition (Minneapolis: Fortress Press, 2016), 39.
} 
Sebagai am YHWH (YHWH's people atau people of God), Israel dipilih dan berada dalam hubungan dengan Allah dan keberadaan Israel terhubung dengan YHWH. Walther Zimmerli ${ }^{25}$ memandang Israel memiliki hubungan yang khusus dalam kaintannya dengan pemilihan. Dalam realitas sehari-hari, pemilihan-election adalah a decision of the will dan ini tidak berbeda dengan yang digunakan dalam Alkitab. Hanya saja, kata ini digunakan oleh Allah dalam kehendakNya yang bebas untuk memilih Israel. Ini adalah kedaulatan Allah untuk memilih Israel dan tidak bangsa yang lain. Israel dipilih menjadi bangsa yang kudus.

Peristiwa keluaran memberikan pengalaman keselamatan dan menjadi fundamental bagi iman Israel. Tidaklah masalah bahwa seseorang dan kemudian orang lain berkumpul di sekitar peristiwa ini, melainkan melihat dirinya ditempatkan dalam komunitas dengan Allah melalui tindakan historis pemilihan ilahi.

Iman ini cukup unik, yang secara historis berbicara, sesuatu yang tampaknya diketahui oleh Perjanjian Lama: "atau apakah ada allah yang pernah datang dan mengambil sebuah bangsa dari bangsa lain melalui penderitaan, tandatanda, keajaiban dan perang, dengan tangan yang kuat dan lengan yang terulur dan dalam kedasyatan, seperti yang telah dilakukan Tuhan Allahmu untukmu di Mesir, di depan matamu. Hal ini ditunjukkan kepadamu sehingga kamu dapat mengetahui bahwa Yahweh adalah Tuhan, tidak ada yang lain selain Dia "(U1. 4: 34). Orangorang ini menamakan dirinya"Israel", dan pada saat yang sama, keduanya sebagai "sebuah masyarakat dan komunitas iman." "Karena YHWH-lah yang masuk ke dalam komunitas dengan orang-orang ini dalam konteks sejarah, Dia juga yang bisa membubarkan hubungan ini. Dengan caranya sendiri, Ulangan (Deuteronomi) mencerminkan pemahaman historis tentang inisiatif ilahi dalam membentuk hubungan dengan Israel (lih Ul. 8:19 dan 9:14), seperti juga teks-teks Deuteronomistik (DtrH) lainnya (2 Raj. 17:7-23). Para nabi juga mengumumkan pemahaman ini dalam penghakiman-penghakiman mereka yang ditujukan kepada Israel dan Yehuda.

Pemilihan Allah yang jatuh pada Israel mewajibkan Israel berada dalam hubungan dengan Allah. Secara historis, kemudian menjadi komunitas iman Yahwis. Keberadaan Israel sebagai umat YHWH menuntut tanggung jawab penuh dari Israel. "Pemilihan menuntut tanggung jawab. Israel masuk dalam hubungan perjanjian dengan Allah.. ${ }^{26}$ Tanggung jawab Israel adalah wajib menaati kewajiban yang dibebankan kepada mereka. Hal itu disampaikan oleh "Musa dalam pindatonya bahwa ada keuntungan yang tersedia bagi mereka, meski kemudian

${ }^{25}$ Walther Zimmerli, Old Testament Theology in Out Line (Edinburgh: T \& T Clark, 1978), 112.

${ }^{26}$ T. Desmond Alexander, From Paradise to the Promised Land: An Introduction to the Pentateuch (Grand Rapids: Baker Book House Company, 2012), 306. 
kitab Ulangan menyoroti konsekuensinya jika Israel gagal memenuhi panggilan itu." 27

\section{Pemilihan, Tanggung Jawab, dan Misi}

Perjanjian Lama mencatat tentang pemilihan Israel sebagai pemilihan ilahi dan pembebasan Israel adalah pembebasan ilahi. Maka "pemilihan memiliki tujuan." 28 Israel harus memahami pemilihan mereka sebagai pemilihan ilahi yang juga memiliki tujuan ilahi. Pemilihan Abraham memiliki tujuan ilahi, olehmu semua kaum di muka bumi memperoleh berkat (Kej. 12:3). Dengan kata lain, "the promises made to the patriachs define the purpose of the election as follows: "by you, all the families of the earth will be blessecf. ",29 Olehmu semua kaum di muka bumi diberkati mengindikasikan, pemilihan disertai tanggung jawab. Walter $\mathrm{C}$. Kaiser meletakan Kejadian 12:3 sebagai dasar misi, bahwa "kol mispehot-all the famillies ${ }^{, 30}$ harus dilihat dalam visi msionaris. Rujukkan Kaiser pada keluarga karena "keluarga adalah unit suku terkecil.",31 Dalam kisah keluaran, Israel disebut sebagai bangsa yang kudus. Sebutan ini merujuk pada Allah, kuduslah kamu sebab Aku kudus. Dalam konteks Deutero Yesaya, Israel menjadi terang bagi bangsabangsa (Yes. 42:6). Kaiser juga melihat pemilihan atas Israel sebagai "panggilan Allah kepada Israel untuk menjadi terang bagi bangsa-bangsa." ${ }^{, 32}$

Pemilihan Israel menuntun Israel pada tanggung jawab menjadi menjadi berkat, hidup kudus, dan menjadi terang. Tanggung jawab ini menunjukkan karakter Allah. Karakter ini harus ditunjukkan Israel sebagai karakter Israel dan berita bagi bangsa lain, ada YHWH di tengah-tengah Israel. Dalam kerangka kerja pemilihan dan misi, hal ini bermakna, pemilihan sebagai pembebasan dan penyelamatan. Israel harus melakukan tugas dimaksud. Kaiser mengatakan, "the election of Israel, far from meaning the rejection of the other nation of the world, was the very means of salvation of the nations. Election was not a call to privilege, but a choosing to service." 33 Israel sebagai komunitas Yahwis memiliki tanggung jawab hanya melayani YHWH dan menyatakan kepada bangsa lain bahwa ada YHWH di tengah-tengah Israel.

$27 \mathrm{Ibid}$.

28 Imchen, "The Election of Israel : A Theological Critique."

$29 \mathrm{lbid}$

30 Walter C. Kaiser Jr, Mission in the Old Testament: Israel as a Light to the Nations (Grand Rapids: Baker Books, 2000), 39.

${ }^{31} \mathrm{lbid}$.

32/bid., 41

33 lbid., 51. 
Seperti Kaiser, panggilan dan pemilihan Israel harus dilihat dalam kerangka "panggilan misi." ${ }^{34}$ Memahami posisi bangsa Israel dalam peta visi Allah atas dunia merupakan sebuah pintu masuk untuk memahami kehendak Allah atas gereja. Urgensitas pemahaman kita atas posisi Israel dalam peta visi Allah adalah agar gereja mengerti maksud pemanggilan, penetapan dan pengutusan Tuhan atas Israel; mengerti reaksi dan aksi Israel dalam menjalani misi tersebut. Memahami panggilan Allah atas Israel merupakan langkah awal dalam memahami peta misi Allah sebab "from Genesis to Malachi Jehovah is portrayed as a missionary God. The Jesus of the New Testament is the Jehovah of the Old. He was the first and great Missionary...."35 Perintah misi berkaitan dengan bagaimana manusia tetap berada di dalam hubungan dan komunikasi dengan Allah. Allah memanggil Israel dan nantinya gereja, adalah agar yang terputus hubungannya dengan Allah dapat mendengar berita misi dan kembali membangun hubungan dengan Allah.

Lima kali Allah berkata, "Aku akan memberkati engkau", "Aku akan memberkati orang-orang yang memberkati engkau," dan "olehmu semua kaum di muka bumi akan mendapat berkat." Meski demikian, pemilihan (boleh kita melihatnya sebagai suatu anugerah) Israel tidak serta merta membuat mereka "besar kepala". "If Jehovah is the God of Israel because he has made a covenant with Israel, it is conceivable that other nations will also some day be included in that covenant. For Israel has no individual and peculiar claim upon God its privileged position is due solely tod God's electing grade. Israel is not better than other nation. ${ }^{36}$ Israel boleh merasakan pemilihan tersebut secara sendiri dalam konteks kesejarahan pemilihan dalam perjanjian (covenant) namun bergerak maju dan menjadi bagian semua bangsa yang mau mengenal Allah.

Menurut Kane, ada tiga tujuan pilihan Allah atas Israel saat kita melihatnya dalam konteks misi, yakni "first, Israel was to be the recipient and guardian of God's special revelation to the world (Heb. 1:1-3). Second, Israel was to be the channel through which the Redeemer was to enter the stream of human history. Third, Israel was to be God's servent and witness in the midst of the nations. "37 Tujuan ini, oleh Harold Cook $^{38}$ juga berkaitan dengan sepuluh hukum Allah (the ten commandments) sebagai bukti legal (legalitas itu dapat dilihat melalui adanya tempat diberikan dan 10 hukum itu sendiri) bahwa Allah telah memilih dan mengutus mereka bahkan Allah pernah berbicara kepada mereka.

\footnotetext{
34 Widjaja and Boiliu, Misi Dan Pluralitas Keyakinan Di Indonesia, 1.

35 J. Herbert Kane, The Christian World Mission. Today and Tomorrow (Michigan: Baker Books, 1986), 16.

36 Ibid., 14.

${ }^{37}$ Harold Kook, An Introduction to Christian Missions (USA: Moody Press, 1974), 61.

38 lbid.
} 
Ketika Israel menerima panggilan tersebut melalui Musa, Israel pada umumnya pada waktu masih berada di Mesir, mereka hanya mengarahkan pandangannya pada bagaimana memperoleh kemerdekaan dari Mesir. Atau pun ketika Musa menyampaikan visi Tuhan atas mereka tentang Kanaan sebagai tujuan akhir mereka, mereka hanya mengerti berita tersebut sebatas "bebas dan memiliki negeri." Pandangan semacam ini tentu akan mengarahkan mereka hanya sebatas memiliki negeri sendiri sehingga mereka menjadi setingkat dengan bangsa-bangsa lain di sekitarnya.

Pemikiran yang diungkapkan di atas dapat ditelusuri dari sikap dan reaksi Israel ketika Musa menyampaikan visi tersebut pertama kalinya bahkan sikap dan reaksi lainnya dapat ditelusuri ketika proses keluar dari Mesir, memasuki dan menetap di Kanaan.

Sikap dan reaksi umum yang dapat dijumpai adalah menafikan panggilan Allah atas mereka sebagai misionaris. Penafikan tersebut dapat dilihat dari sikap mereka untuk tidak terpaut kepada Tuhan, tegar tengkuk, dan lain-lain. Sikap-sikap ini menunjukkan bahwa mereka tidak memiliki tanggungjawab misi atau tidak melihat posisi mereka sebagai misionaris Tuhan di tengah-tengah bangsa kafir.

Berkaitan dengan mandat misi Allah kepada Israel, maka kita dapat mengerti konsep misi. Konsepnya adalah setiap orang yang belum mengenal Allah baik dalam konteks Perjanjian Lama maupun Perjanjian Baru harus mengenalnya melalui Israel (PL) dan melalui gereja Tuhan (PB). Wilayahnya meliputi seluruh dunia yakni yang belum mengenal dan menerima Tuhan (Kristus).

Israel dalam Perjanjian Lama dan gereja dalam Perjanjian Baru, samasama mengemban tugas sebagai misionaris. Ini berarti bahwa mereka harus melaksanakan mandat. Dalam konteks Perjanjian Lama, tidak ada keharusan untuk menjadi warga Israel sebagai representasi berada di dalam Tuhan. Melainkan menunjukkan melalui sikap tunduk dan menyembah hanya kepada YHWH. Sedangkan di Perjanjian Baru, memang tidak ada keharusan untuk berada di dalam gereja namun tidak mungkin mengenal Allah dan menandainya jika tidak di dalam gereja. Ini berarti bahwa tidak ada jaminan bahwa yang berada di dalam gereja "pasti selamat", sejalan dengan itu juga tidak mungkin ada jaminan pengajaran yang benar jika tidak "di dalam gereja."

Misi bukanlah tugas pertama dan terakhir melainkan misi ada di dalam proses menjadi milik Kristus seutuhnya. Yakni, yang telah mengenal Allah (Kristus, baik PL maupun PB) di pundaknya tugas misi diletakan. Ini berarti semua orang percaya adalah misionaris. Proses selanjutnya adalah menjadikan semua murid Kristus, yakni yang telah mengenal dan menerima Kristus. 


\section{HASIL DAN PEMBAHASAN}

Tema "pemilihan-election" merupakan salah satu tema teologis penting dalam teologia Perjanjian Lama. Tema pemilihan menempati posisi penting ketika membahas "perjanjian" ${ }^{\text {"39 }}$-covenant. Allah dan Israel masuk dalam tahap perjanjian setelah Allah memilih Israel dan Israel menempati posisi sebagai umat pilihan Allah (YHWH). Pemilihan Israel tidak didasarkan pada unsur pemenuhan persyaratan yang diajukan Allah melainkan pemilihan itu didasarkan pada pemilihan Allah sebagai pribadi yang bebas.

Tema teologis "perjanjian", meskipun menjadi tema penting dalam teologia Perjanjian Lama, tetap tidak menjadi penting bila tidak ada orang (individu $^{40}$ atau kelompok tertentu dipilih atau terpilih menjadi pihak yang dengannya pemilih mengadakan perjanjian. Pemilihan menjadi hak tunggal Allah. Dalam pemilihan ini, terbentung tanggung jawab yang harus diemban oleh Israel. Diawali dengan pemilihan "individu (Abraham)",4142 menuju "pemilihan bangsa atau komunitas." ${ }^{, 43}$

Tanggung jawab Israel terhadap Allah sebagai pemilih merupakan kerang kerja dari respons Israel terhadap pemilihan dan perjanjian. Mempertahankan dan tetap berada dalam tanggung jawab Israel terhadap pemilihan dan perjanjian sebagai poin penting hubungan Allah-Israel. "Perjanjian sebagai pengikat hubungan" ${ }^{, 44}$ dan pengesahan pemilihan. Sehingga tetap berada dalam "hubungan dan komunikasi yang kondusif." ${ }^{45}$ Sisi lain dari tanggung jawab Israel adalah bersifat misional. ${ }^{46,47}$

Ada perkembangan narasi dalam Perjanjian Lama, dari pemilihan individual ke pemilihan kelompok atau komunitas, di mana keluarga menjadi lokus terkecil dalam suku (mengacu pada pemikiran Kaiser). "The purpose of the family: a Christian perspective on the contemporary home is to present an integrated vew of contemporary family life which is base upon social-science researh, clinical

\footnotetext{
${ }^{39}$ Walter Brueggemann, Teologia Perjanjian Lama: Kesaksian, Tangkisan, Pembelaan (Maumere: Seminari Tinggi Ledalero, 2009), 254-256. Janii sebagai substansi dan memberkati atau memberi.

40Ibid., 254. Secara historis pemilihan individu dilihat melalui Abraham dan Abraham menerima janji sebagai janji dalam narasi para leluhur.

${ }^{41}$ Rolf Rendtorff, The Old Testament. An Introduction (Philadelphia: Fortress Press, 1991), 6.

${ }^{42 H}$. D. Preuss, Old Testament Theology (Kentucky: Westminter, 2007), 28.

${ }^{43}$ lbid., 30.

${ }^{44}$ Harriet Jane Olson, ed., The New Interpreters Bible: Old Testament Survey (Nashville: Abingdon Press, 2005), 26.

${ }^{45}$ B. C. Birch, Let Justice Roll Down. The Old Testament, Ethics, and Christian Life, 1st ed. (Louisville: Westminter, 2009), 145. Israel sebagai "People of the Covenant". Perjanjin diinisiasi oleh Allah. Perjanjian menuntun pada terminologi karakter Allah.

${ }^{46}$ Fransiskus Irwan Widjaja and Noh Ibrahim Boiliu, Misi Dan Pluralitas Keyakinan Di Indonesia (Yogyakarta: Andi Offset, 2020), 1-6.

${ }^{47}$ Noh Ibrahim Boiliu, "Kesinambungan Panggilan Misionaris Bangsa Israel Dengan Panggilan Pelayanan Misi Dan Pemuridan," Te Deum 4, no. 2 (2015): 209-223.
} 
insights, and biblical truth. ${ }^{48}$ Jack dan Judith melihat operasionalisasi keluarga pada konteks kontemporer adalah mengikat unsur-unsur keilmuan dalam satu perspektif. Perspektif psikologi positif harus ditambahkan sebagai unsur yang membantu orang menemukan cara hidup yang lebih baik dan membantu mengenali diri sebagai orang yang sehat mental. "Fungsi keluarga sebagai sebuah sistem sosial" ${ }^{49}$ adalah menjaga keharmonisan hubungan seperti "hubungan Allah dengan Israel sebagai anaknya." ${ }^{50}$ Allah menuntut tanggung jawab Israel dalam dua segi: ke dalam dan keluar. Ke dalam, Israel harus memastikan tugas pengajaran telah berjalan dengan baik (Ulangan 6:6-9) sebagai fondasi dan tugas keluar, yakni pemberitaan atau kesaksian. Ini dapat tercapai bila keharmonisan kelurga terjaga maka pengajaran di tingkat keluarga dapat berjalan baik. "Mejaga komitmen untuk mendemonstrasikan kasih Allah, kepedulian, tanggap, disiplin, memberi, respek, mengenal (i) dan mengampuni" merupakan fitur-fitur dalam menjaga keharmonisan hubunga." ${ }^{51}$

Maka kesaksian Perjanjian Lama mendorong tanggung jawab pada kelompok dengan mengacu pada keluarga untuk mencapai tujuan. Secara teknis Taurat (kita baca dan pahami dalam tradisi Kristen sebagai Firman Tuhan) sebagai "pengetahuan" dan pengajaran otoritatif. Keluarga Kristen masa kini menempati lokus pertama. Keberhasilan di tingkat keluarga menjadi kekuatan untuk tugas pemberitaan (kerygma) keluar. Pendidikan Agama Kristen (keluarga sebagai ruang lingkup) sebagai pendekatan untuk meletakan tugas misi sebagai usaha membangun dan mempertahankan dari dalam. Dalam perspektif ini juga, keluarga menjadi basis untuk teologia pendidikan (Agama Kristen), di mana keluarga merupakan salah satu ruang lingkup dalam kajian Pendidikan Agama Kristen (PAK dalam Keluarga).

\section{KESIMPULAN}

Pokok pemilihan menempati posisi penting dalam pembahasan perjanjian atau covenant. Allah dan Israel masuk dalam tahap perjanjian setelah Allah memilih Israel dan Israel menempati posisi sebagai umat pilihan Allah (YHWH). Pemilihan Israel tidak didasarkan pada unsur pemenuhan persyaratan yang diajukan Allah melainkan pemilihan itu didasarkan pada pemilihan Allah sebagai pribadi yang bebas.

\footnotetext{
48 Jack O. Balswick and Judith K. Balswick, The Family: A Christian Perspective on the Contemporary Home (Grand Rapids: Baker Books House, 1989), 11.

49 Ibid., 19.

50 lbid., 21.

51 lbid.
} 
Pemilihan Israel oleh Yahweh menempatkan Israel sebagai komunitas atau umat Yahwis. Pemilihan Israel membawa Israel pada tanggung jawab hanya menyembah Yahweh dan "memopulerkan" Yahweh di antara bangsa-bangsa non Yahwis. Ini adalah konsekuensi logis atas pemilihan tersebut. Berbanding lurus dengan tanggung jawab memopulerkan Yahweh, Israel harus membangun pondasi dan tanggung jawab misi di dalam dan melalui keluarga. Tanggung jawab ini bersifat futuristik sebab anggota keluarga, dalam hal ini anak menjadi target utama. Pada tataran inilah, pemilihan dan tanggung jawab Israel menjadi basis pencarian (hingga penemuan) misi dalam teologia pendidikan Agama Kristen. Di mana keluarga menjadi lokus praksis. Oleh karena itu, misi yang berhasil harus dimulai dari keluarga dengan pendekatan PAK Keluarga. Sejalan dengan ini, gereja bertanggungjawab menyiapkan keluarga dan anak-anak melalui kelas-kelas teologia praktis di gereja, bagi orang tua dan anak sebagai tindakan komprehensif.

\section{KEPUSTAKAAN}

Alexander, T. Desmond. From Paradise to the Promised Land: An Introduction to the Pentateuch. Grand Rapids: Baker Book House Company, 2012.

Baden, Joel S. The Composition of the Pentateuch: Renewing the Documentary Hypothesis. New Haven \& London: Yale University Press, 2012.

Balswick, Jack O., and Judith K. Balswick. The Family: A Christian Perspective on the Contemporary Home. Grand Rapids: Baker Books House, 1989.

Birch, B. C. Let Justice Roll Down. The Old Testament, Ethics, and Christian Life. 1st ed. Louisville: Westminter, 2009.

Boiliu, Noh Ibrahim. "Kesinambungan Panggilan Misionaris Bangsa Israel Dengan Panggilan Pelayanan Misi Dan Pemuridan.” Te Deum 4, no. 2 (2015): 209223.

Brueggemann, Walter. Teologia Perjanjian Lama: Kesaksian, Tangkisan, Pembelaan. Maumere: Seminari Tinggi Ledalero, 2009.

Carr, David M. Introduction to the Old Testament: Sacret Text and Imperial Context of the Hebrew Bible. Oxford: Wiley Blackwell, 2010.

Imchen, S. Temjen. "The Election of Israel : A Theological Critique." Indian Journal of Theology 1, no. 2 (2001): 23-29.

Kaiser Jr, Walter C. Mission in the Old Testament: Israel as a Light to the Nations. Grand Rapids: Baker Books, 2000.

Kane, J. Herbert. The Christian World Mission. Today and Tomorrow. Michigan: Baker Books, 1986.

Kook, Harold. An Introduction to Christian Missions. USA: Moody Press, 1974. McKeown, J. Dictionary of the Old Testament: Pentateuch. Edited by T. Desmond 
Alexander and David W. Baker. Downers Grove, IL: Intervarsity Press, 2003. Muddiman, John, and John Barton, eds. The Pentateuch: Oxford Bible Commentary. Oxford: Oxford University Press, 2010.

Olson, Harriet Jane, ed. The New Interpreters Bible: Old Testament Survey. Nashville: Abingdon Press, 2005.

Ott, Bernhard. "Mission and Theological Education" 18, no. 2 (2016): 87-98.

Preuss, H. D. Old Testament Theology. Kentucky: Westminter, 2007.

Rendtorff, Rolf. The Old Testament. An Introduction. Philadelphia: Fortress Press, 1991.

Seters, John van. The Pentateuch: A Social-Science Commentary. England: Sheffield Academic Press, 1999.

Sohn, Seock Tae. The Divine Election of Israel. Oregon: Wipf and Stock Publishers, 1991.

Tizon, Al. "Mission as Education : A Past-to- Future Look at INFEMIT / OCMS" 4, no. 28 (2011): 253-264.

Widjaja, Fransiskus Irwan, and Noh Ibrahim Boiliu. Misi Dan Pluralitas Keyakinan Di Indonesia. Yogyakarta: Andi Offset, 2020.

Woo, Wesley. "MISSION DEVELOPMENT: Practical Confession Seminar Presentations on Themes" 61, no. 1 (2015): 162-166.

Yee, Gale A., Hugh R. Page Jr, and Matthew J.M Coomber, eds. The Pentateuch: Fortress Commentary on the Bible Study Edition. Minneapolis: Fortress Press, 2016.

Zimmerli, Walther. Old Testament Theology in Out Line. Edinburgh: T \& T Clark, 1978. 